Of this handsome species I have seen only four colonies, all taken in Travis County, Texas. Three of these were in oak logs that had been brought to Austin by the crackers from the mountain cañons northwest of the city. The remaining nest was found in Bull Creek Cañon in a crevice between two huge rocks. The males and winged females were taken in two of the nests Feb. 28, I901, and March 25,1902 .

C. texanus appears to be closely related to C. sayi Emery of Arizona and Mexico. It is sufficiently distinct, however, both in size, coloration, shape of clypeus, petiole, etc.

April I 5, I903.

\title{
A NEW GENUS AND FOUR NEW SPECIES OF ASILIDAE.
}

BY CHARLES W. JOHNSON, BOSTON, MASS.

Ceraturgopsis, gen. nov.

Type. - Dasypogon cornutus Wiedemann, Auss. Zw. Ins., I, 382, 1828.

This species has been placed by Baron Osten Sacken in the synonymy under Ceraturgus cruciatus Say. At the time of writing my paper on the Diptera of Florida (Proc. Acad. Nat. Sci. Phila., I895, p. 303-304) I did not possess examples of Say's species, and as Wiedemann's species agrees quite closely in color-pattern I assumed that the synonymy was correct. Since obtaining specimens of $C$. cruciatus I was somewhat surprised to find a great difference in the antennae, so much so that $D$. cornutus cannot remain in the genus Ceraturgus. The antennae are so accurately described by Wiedemann, as to leave no doubt as to the species : "Erstes Fühlerglied röthlich, die folgenden schwarz: erstes und zweites von gleicher Läng€; das dritte fast viermal so lang als eines von jenen, an der Spitze ein wenig verdickt; das erste der beiden Spitzenglieder sehr klein, fast verkehrt kegelförmig das letzte zusammengedrückt eirund, noch einmal so lang als das vorhergehende, mit einem sehr kurgen Seitendörnchen."

The terminal joint has a slight lobe-like projection bearing a small spine as shown in Fig. 3. In $C$. cruciatus the terminal joint is elongated and densely pubescent (Fig. 2). The rare Ceraturgus aurulentus Fabr., also resembles $C$. cornutus, but the form of the antennae (Fig. r), hyaline wings, and smaller size readily separates it from that species. I have seen but three specimens of $C$. aurulentus, one taken by myself at Westville, N. J., August 2 I, 1892; the others 
collected by Mr. E. Daecke at Castle Rock, Delaware Co., Pa., and at Lehigh Gap, Pa., July I I, by Chas. T. Greene. It is the type of the genus Ceraturgus Wied.

The specimens of $C$. cornutus were collected by Mrs. Annie T. Slosson at Ormond, Florida, in April.

\section{Dizonias pilatei, sp. nov.}

The specimen ( $q$ ) on which this species is based was collected by Mr. G. R. Pilate at Tifton, Georgia, Sept. 9, r896, and was received from Dr. Garry de N. Hough. I had placed it doubtfully with that variable species, $D$. tristis Walk. (D. bicinctus Loew.). After carefully comparing it with eleven specimens of that species in my collection from St. Augustine, Fla., and Opelousas, La., collected in June, I submitted the specimen to Mr. D. W. Coquillett who also considered it distinct from $D$. tristis.

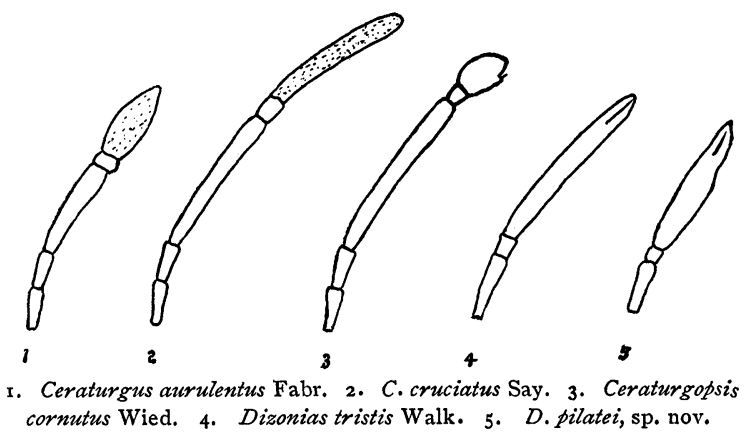

This species is distinguished from $D$. tristis in having the thorax noticeably narrower; the third joint of the antennae (Fig. 5) shorter, proportionately broader and entirely red; the mystax finer less profuse and whitish, not red; abdominal segments one to five each bearing a broad basal band of yellow, those on the second and third occupying the entire lateral margin and gradually narrowing towards the dorsum, segments five to eight bright red, not black; wings decidedly narrower, brown, with the discal portions and margin of the veins yellowish. Length $16 \mathrm{~mm}$.

It should also be noted that the great difference between the two species in their time of appearing, also shows that they are in no way related, as all data pertaining to the Asilidae indicate but one seasonal brood. 


\section{SAROPOGON BICOLOR, sp. nov.}

§. Head black, mystax and pubescence of the face yellow, antennae reddish, becoming dark brown towards the tip; proboscis black, slightly brownish at the base. Thorax black, with a large quadrate humeral spot from which extends a lateral line of the same color to the base of the scutellum, minute pustules, bearing short hairs give the entire body a punctated appearance; pleurae and scutellum black, lateral angles of the scutellum and metanotum brownish, pleurae shining. First and seventh segments of the abdomen black, the others red, with a lateral margin of black, the second segment has a narrow continuous posterior margin of black, on the others it extends but a slight distance from the lateral margin; venter black. Halters and legs reddish, coxae, tips of the posterior femora and base of the tibiae, with a very narrow ring of black, the last joint of the front and middle tarsi also black, spines on the tibiae few in numbers and mostly white, those on the tarsi numerous and black. Wings with a light brownish tinge, the veins on the basal half bright yellow; the fourth posterior cell closed and slightly petiolate. Length $12 \mathrm{~mm}$.

One specimen said to have been taken near San Antonio, Texas, was given to me by the late Andrew Bolter.

\section{SAROPOGON abBreviatus, sp. nov.}

§. Similar in form to the preceding but the entire body, legs and antennae are a deep black, with the same punctated appearance; mystax for the most part black. Halteres yellow. Wings brown, the veins black, fourth posterior cell narrowly open. Length I2 $\mathrm{mm}$.

Obtained with the preceding specimen and may prove to be only a variety, but with so limited material I am not justified in uniting them. The difference in the fourth posterior cell cannot be relied on even as a specific character, as it varies even in the same species. Among the four specimens of $S$. adustus in my collection, two have it closed and slightly petiolate, while in the other two it is narrowly open. The same variation exists in S. combustus; nor is it sexual.

Near San Antonio, Texas.

Atomosia sayis, sp. nov.

This name is applied to the variety referred to by Say under "Laphria glabrata" as "Var. a. Feet pale" (Journ. Acad. Nat. Sci. Phila., III, 54, r823.)

It is very evident that Say had two species before him, and that the name and description can only apply to the one with - "feet reddish brown, the middle of the 
thighs, tips of the tibia and tarsi darker." The markings on the femora really consists of a large patch of black occupying the greater portion of the upper side of the front and middle femora, and the upper side of the outer half of the posterior femora. The only specimens in my collection were taken in Fairmount Park, Philadelphia, Aug. 4, I892, and Castle Rock, Delaware Co., Pa., Aug., I I I 190 I (E. Daecke) Atomosia rufipes Macquart is undoubtedly a synonym.

In $A$. puella Wied. the legs are black except a narrow ring of yellow at the base of the femora, and tibiae; antennae entirely black. The species is widely distributed, appearing in the Gulf States in May, and in the vicinity of Philadelphia late in June or early in July. $A$. pusilla Macq. can also be added to the synonymy.

In $A$. sayii the legs are pale yellow, with a minute spot at the base of the posterior femora, terminal joint of the tarsi, and claws blackish; the third joint of the antennae are noticeably longer than in either $A$. glabrata or $A$. puella; the second joint being brown. In its habits $A$. sayii differs considerably from the others. On July 23, I893, at Folsom, Delaware Co., Pa., I captured over 75 specimens of both sexes, and invariably on the leaves and terminal shoots of plants; while $A$. puella and $A$. glabrata are as a rule found on stumps, logs, or the trunks of trees.

Its distribution is similar to $A$. puella, but appearing somewhat later: Opelousas, La., June (Pilate); in the vicinity of Philadelphia, July 23 to $3 \mathrm{I}$.

Atomosia soror, Bigot from Lower California, resembles $A$. sayii in having pale yellow legs; but is distinguished by the lighter colored antennae, the more abundant, prostrate, yellow hairs on the thorax and abdomen, and red post-alar protuberance. 

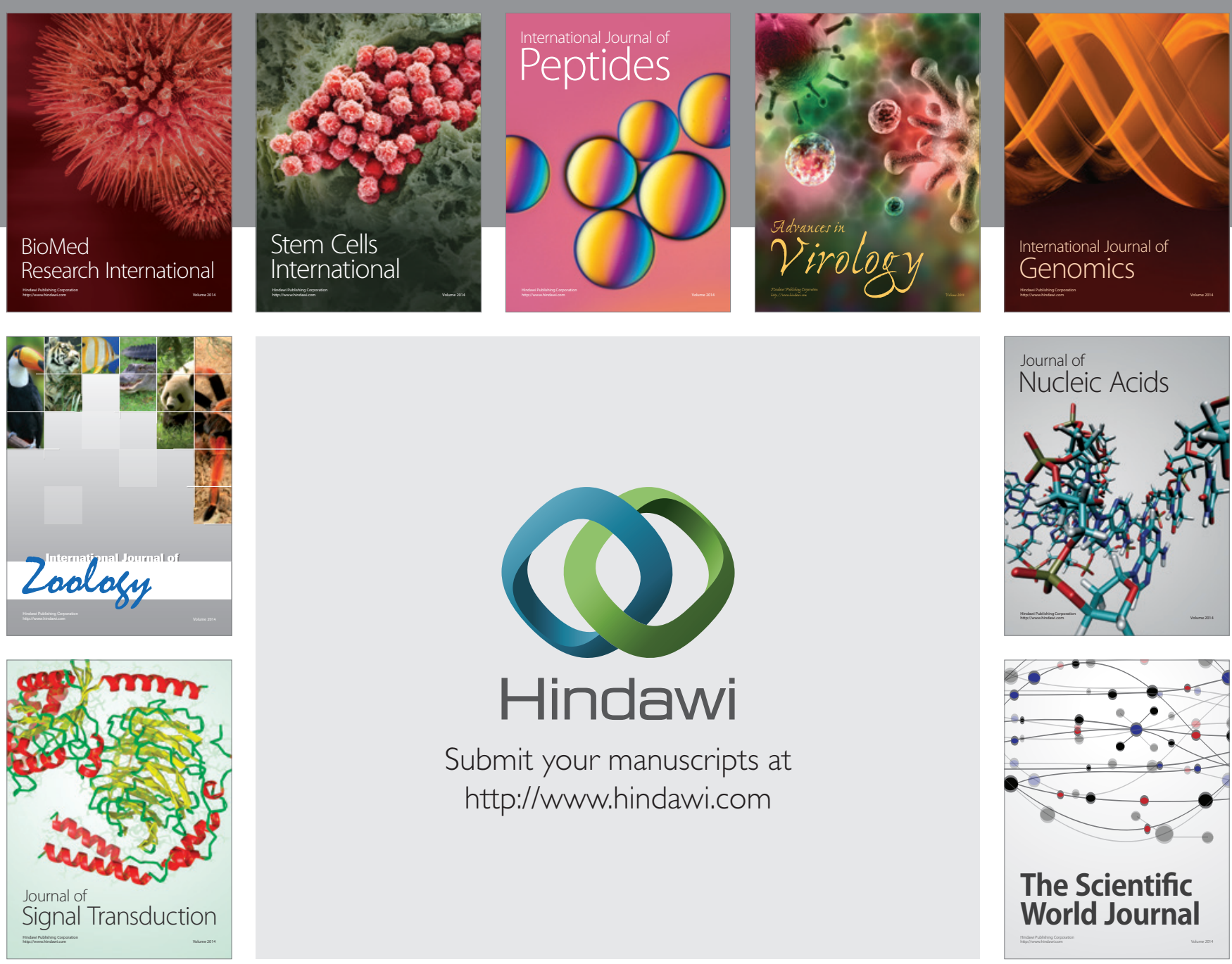

Submit your manuscripts at

http://www.hindawi.com
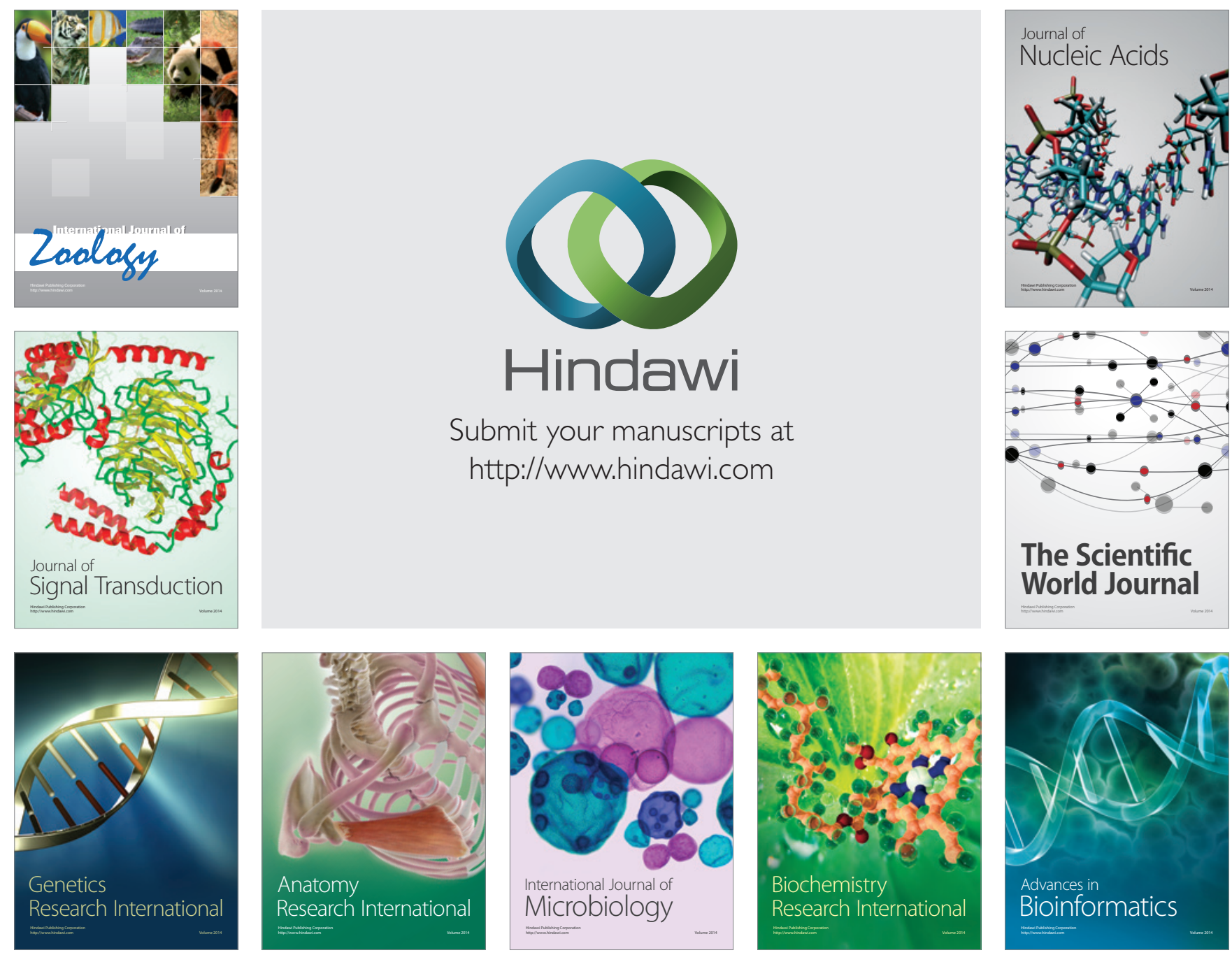

The Scientific World Journal
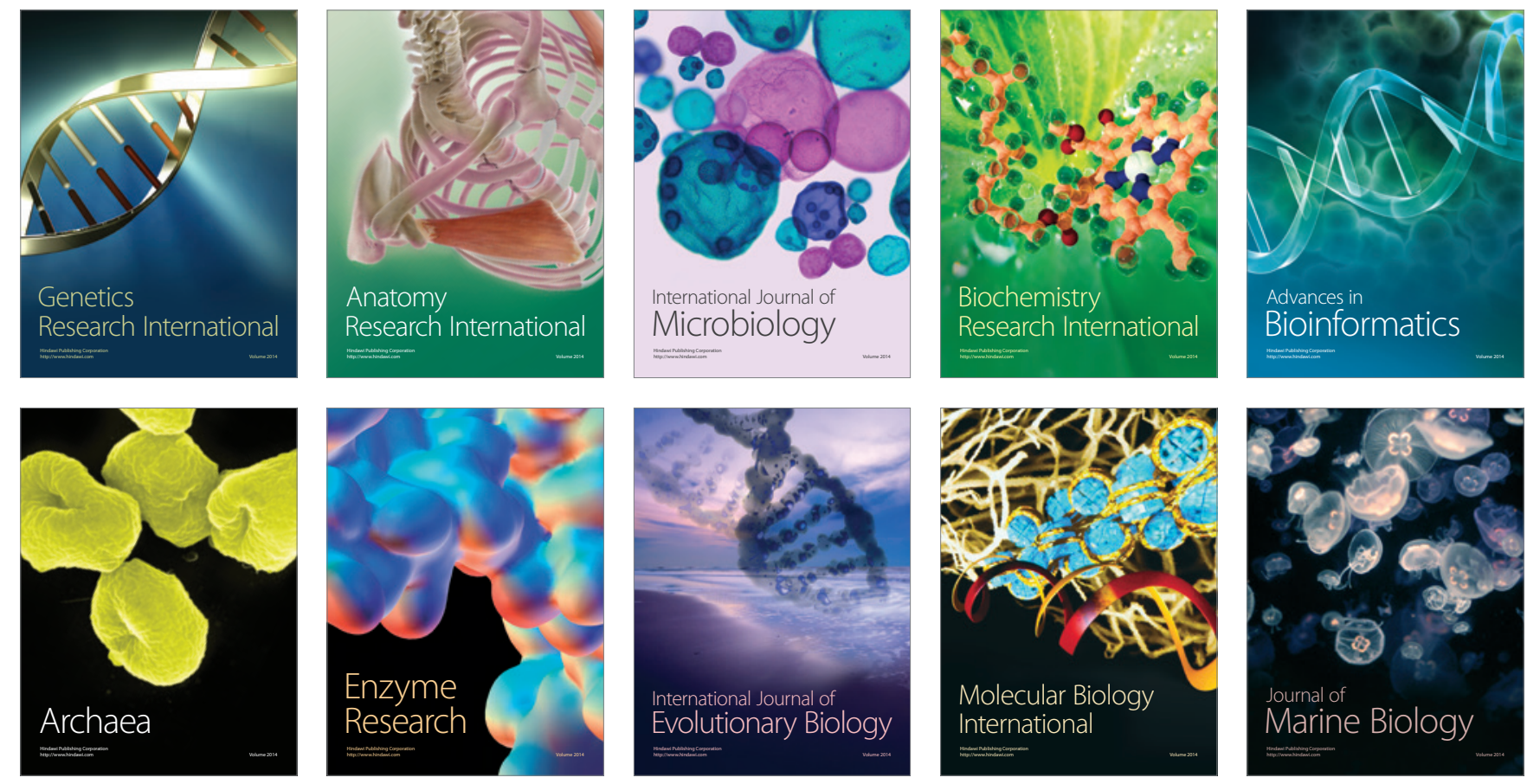